\title{
DESIGN OF WEB BASED ACADEMIC INFORMATION SYSTEM IN MADRASAH IBTIDAIYAH NURUL FALAH DEPOK
}

\author{
Ibnu Rusdi, Bekti Kurniasih \\ 1 Teknik Informatika \\ Sekolah Tinggi Manajemen Informatika dan Komputer Nusa Mandiri \\ www.nusamandiri.ac.i \\ ibnu.ibr@nusamandiri.ac.id \\ 2 Sistem Informasi Akuntansi \\ Universitas Bina Sarana Informatika \\ www.bsi.ac.id \\ 2 11170668@bsi.ac.id
}

\begin{abstract}
Abstrak
Madrasah Ibtidaiyah Nurul Falah Depok masih belum memiliki sistem yang dapat secara luas diakses karena masih belum terkomputerisasi seperti umumnya pada umumnya belum memanfaatkan teknologi secara maksimal. Pemberian nilai ulangan harian, ujian tengah semester (UTS), ujian akhir semseter (UAS) masih dikerjakan oleh guru atau pengajar. Siswa pada sekolah tersebut tidak dapat secara langsung melihat nilai yang diberikan oleh guru atau pengajar karena nilai akhir diberikan pada saat semua sudah direkap dan dalam bentuk rapot di akhir semester. Metode penelitian yang digunakan adalah metode kuantitatif dan terapan sehingga dengan menggunakan dua metode tersebut dapat memberikan kontribusi yang baik pada penelitian dan pengembangan sistem informasi yang dirancang dan akan dipergunakan pada MI Nurul falah. System Development life Cycle yang digunakan dalam pengembangan software ini adalah model Waterfall dengan beberapa tahap yang dimulai dari analisis, desain, pengkodean dan testing. Untuk perancangan database yang diusulkan berupa ERD dan LRS, untuk perancangan sistem menggunakan UML. Tujuan penelitian diharapkan software yang dibangun dapat dimaksimalkan dari sisi pengamanan data dan pemanfataannya dalam bidang akademik dan non akademik. Hasil dari penelitian informasi yang terkait akademik mengenai akses terhadap nilai dan pengmuman lainnya sangat penting agar menjadi motivasi bagi siswa untuk mempersiapkan diri lebih baik lagi serta giat belajar dalam menghadapai proses pembelajaran pada satu semester sehingga dengan terbukanya akses informasi tersebut memudahkan juga bagi orang tua untuk dapat memantau serta mengontrol putra-putrinya dalam bidang prestasi akademik.
\end{abstract}

Kata kunci: Sistem Informasi, Akademik, Model Waterfall

\begin{abstract}
Madrasah Ibtidaiyah Nurul Falah Depok still does not have a system that can be widely accessed because it is still not computerized, as in general it has not made full use of technology. Giving daily test scores, midterm exams (UTS), semseter final exams (UAS) are still being done by teachers or teachers. Students at these schools cannot directly see the grades given by the teacher or teacher because the final grades are given when all have been recapitulated and are in the form of report cards at the end of the semester. The research method used is quantitative and applied methods so that using these two methods can make a good contribution to the research and development of information systems that are designed and will be used in MI Nurul Falah. The System Development Life Cycle used in this software development is the Waterfall model with several stages starting from analysis, design, coding and testing. To design the proposed database in the form of ERD and LRS, for system design using UML. The research objective is expected that the software built can be maximized in terms of data security and its use in academic and non-academic fields. The results of research related to academic information regarding access to grades and other notices are very important in order to motivate students to prepare themselves better and study actively in facing the learning process in one semester so that access to this information makes it easier for parents to be able to monitor and control their children in the field of academic achievement.
\end{abstract}

Keywords: Information Systems, Academic, Waterfall Model 


\section{INTRODUCTION}

The information that is circulating is becoming more numerous and more complex as technology develops rapidly in the current era of globalization. Therefore, the world of education must be able to keep up with these technological developments, especially in terms of computer technology, with the development of technology at this time, the information needed by the community is easily fulfilled because of the presence of the internet, to transfer information can also be done in a matter of seconds. Madrasah Ibtidaiyah Nurul Falah Depok is one of the schools that does not yet have a computerized information system, so to get information from parents, students and teachers must come to school. This results in the teaching and learning process being hampered in communication and the smooth operation of school management (Yuliani, Yunita, \& Amalia, 2018). Currently the Covid-19 pandemic has hit Indonesia and the world in general, so that the implementation and monitoring of education quality does not decrease, the distance education system (PJJ) is a must for schools to carry out the learning process. A new curriculum needs to be compiled and enforced to simplify the material without reducing the quality of education (Tan, 2020). Education is an aspect that plays an important role in human life. The existence of education and progress are interrelated and cannot be separated. In fact, it is never separated from the role of education for the progress of a nation (Novalita, 2017). In previous research, with this academic information system, Pasar Minggu SMK could provide a faster solution in processing values, making reports more effective and efficient because data storage is already in the database (Susanti, 2016). The author tries to design an academic information system to make it easier for teachers to provide student presence, provide daily test scores, semester midterms and final semester exams for students and female students at MI Nurul Falah Depok. The author in designing a web-based system so that it can be accessed easily and made with a dynamic user interface. To produce reliable quality human resources, it must be supported by the quality of educational facilities and infrastructure, because facilities and infrastructure are one of the important factors in supporting student learning (Anam, 2018). The system development model used in this study is the Waterfall model (Aediyansyah, 2018). The purpose of developing an academic information system is so that students can access information on the results of academic evaluation for one semester which has been attended by students and students and in the future it is hoped that it can also be accessed by parents so that it makes it easier for the school to deliver the final results of the semester without having to come to school considering that there is still a pandemic. covid-19.

\section{RESEARCH METHODOLOGY}

\section{Types of research}

This research uses quantitative and applied approaches. Research targets / subjects (for qualitative research) or populations (for quantitative research) need to be described clearly in this section (Friyadie \& Fatayat, 2019). The findings of applied research can be applied to solve problems (Hayati, 2019).

\section{Time and Place of Research}

The research was conducted by taking primary data (directly) to the research locus, namely Madrasah Ibtidaiyah Nurul Falah Depok which was held from April 2020 to 19 June 2020.

\section{Research Targets}

Building a web-based academic information system, so that information related to the academic field can be easily accessed by the community at Madrasah Idtidaiyah Nurul Falah Depok which is more effective and efficient with conveniences tailored to user needs.

\section{Data, Instruments, and Data Collection Techniques}

To support this research, the authors use the following data collection techniques:

1. Observation

This method is carried out by direct observation to obtain data related to academic information currently running at Madrasah Ibtidaiyah Nurul Falah Depok.

2. Interview

This method is a form of data collection by holding direct questions and answers regarding the need for academic information systems to administrative staff at Madrasah Nurul Falah about the object to be studied.

\section{Literature review}

In this technique, the author looks for or digs up information or knowledge from various references from books, journals, official websites on internet pages that provide relevant information related to the object of research discussed in writing.

\section{System Development Model}


According to (Sukamto \& Salahudin, 2018) argues that the SDLC waterfall model is often called a linear sequential model or classic life cycle. The waterfall model provides a sequential or sequential software life flow approach starting from the analysis method, design method, coding method, testing and support stage methods (Lesmono, 2019). The following is an explanation of the five stages of the model:

1. Software Requirements Analysis

At this stage an exploration of the needs of the user is carried out. This academic information system will be implemented on a web-based system, because this web-based system is easily accessible anywhere.

2. Design

After the need for the development of academic information systems has been identified, a system design will be carried out. Database design uses Entity Relationship Diagram (ERD), Logical Record Structure (LRS) and for system design using Unified Modeling Language (UML).

3. Code Generation (Encoding)

The process of making coding or coding is the translation of the design into a language that can be recognized by the computer, the programming languages used are PHP, HTML, CSS, and Java Script and database. The author uses bootstraps with dynamic web display features and User Friendly.

4. Testing

The most suitable testing technique for testing web-based academic information systems is by using Web Application Load, Stress and Performance Testing (WAPT) and Vulnerability. Because with this technique, web-based application testing can be obtained as expected in terms of data access and security.

5. Support

In supporting the information system to be worked on, hardware is needed, namely equipment in physical form that runs the software (software) and this equipment functions to carry out instructions given and issue it in the form of information.

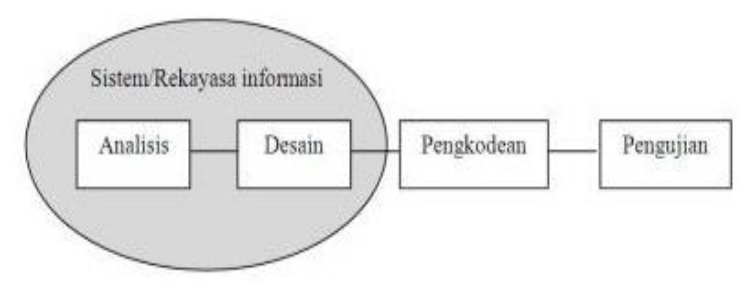

Figure 1. Waterfall Model Illustration
Based on the documents that the author obtained while conducting research at Madrasah Ibtidaiyah Nurul Falah Depok, at the beginning, identified the input and output documents and other supporting documents. After everything is checked and categorized, a database design is made which will be used in the storage, calling and displaying data processing results that will be processed by the software and as a design to make it easier to design the application using the Unified Modeling Language (UML).

\section{RESEARCH RESULTS AND DISCUSSION}

\section{A. Software Requirements Analysis}

The first step taken in the applied thesis management design, the authors identify the needs obtained based on user needs and system requirements. This page is divided into three views. The first screen is for admin, the second is for Teachers, and the third is for Students.

1. Pages For the Admin

Admin can process master data such as teacher/employee data, student data, subject data, class data, scheduling, setting the display or not, controlling value input, providing academic announcements.

\section{Pages For Teachers}

The teacher can attend school attendance, after which the teacher can see the teaching schedule, do student attendance, input the daily test scores, UTS and UAS. Print class attendance recap, print a recap of scores (daily test scores, UTS scores, UAS scores, final grades). Teachers / Lecturers can view student announcements and master data.

3. Pages For Students

Students can view lesson schedules, find out who is teaching. See the results of the UTS, UAS and final scores.

\section{B. Design}

\section{Software Design}

1. Designing Software Systems

This Academic Information System design using Use Case diagrams. Use Case Diagrams describe the relationship between actors and the activities they can carry out on the application (Sukamto \& Salahudin, 2018).

\section{Data analysis technique}




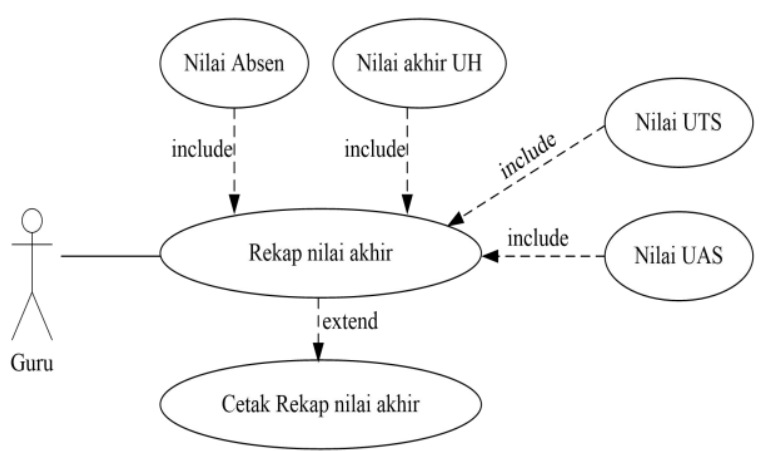

Figure 2. Use Case Diagram Academic Information System Final Score

Table 1. Use Case Scenarios Final Value Recap

\begin{tabular}{|c|c|c|}
\hline Use Case Name & : & Recap students final grades \\
\hline Brief Description & : & $\begin{array}{l}\text { This diagram depicts the final } \\
\text { grade processing process, } \\
\text { where the final score is } \\
\text { obtained from the } \\
\text { accumulated attendance } \\
\text { scores, daily test scores, UTS } \\
\text { scores and UAS scores. This } \\
\text { final grade will be the grade in } \\
\text { the final report card at the end } \\
\text { of the semester. }\end{array}$ \\
\hline Actors & : & Teacher, Admin \\
\hline Pre-Condition & : & $\begin{array}{l}\text { The final grade is complete } \\
\text { after all values have been } \\
\text { entered. }\end{array}$ \\
\hline Main Flow & : & $\begin{array}{l}\text { The teacher inputs the overall } \\
\text { value, and when the teacher } \\
\text { clicks the recap of the final } \\
\text { grade, the teacher gets the } \\
\text { results of the system } \\
\text { processing against the already } \\
\text { existing scores inputted. }\end{array}$ \\
\hline Alternatif Flow & : & $\begin{array}{l}\text { The teacher can print a recap } \\
\text { of the final grade. }\end{array}$ \\
\hline Post- Condition & : & $\begin{array}{l}\text { The teacher gets the final } \\
\text { grade report after the value } \\
\text { input process is complete. }\end{array}$ \\
\hline
\end{tabular}

2. Database Design

The design of the main database using the Entity Relationship Diagram (ERD), by identifying the types of entities and attributes.

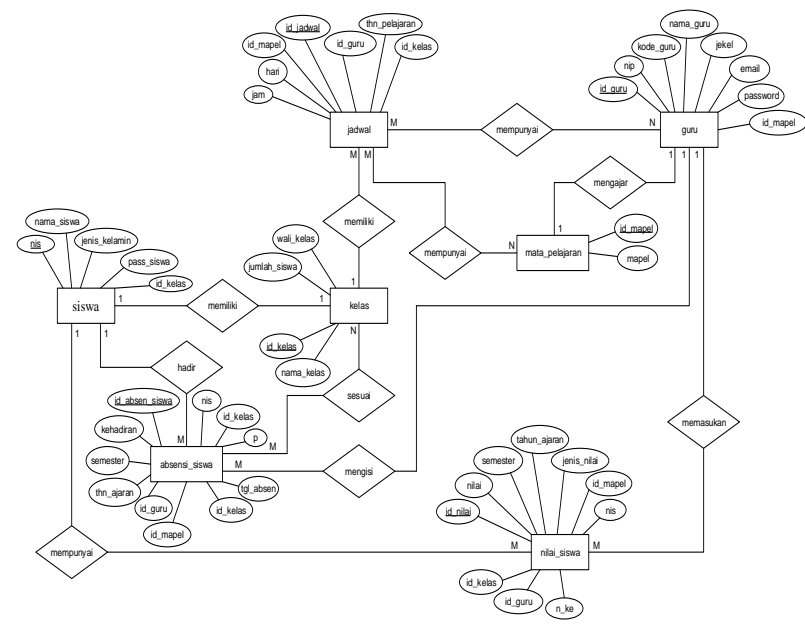

Figure 3. Entity Relationship Diagram (ERD) Academic Information System MI Nurul Falah

The Entity Relationship Diagram above is a form of model to explain the relationship between data in a database.

According to (Rahman \& Pramastya, 2019) Logical Record Structure is a database modeling used to implement ERD designs into a real database. According to (Frieyadie, 2019) The rules that apply to transforming ER-Digram to LRS, are as follows:

a. Each Entity will be converted into a box with the Entity name outside the box and its attributes inside the box.

b. A Relationship is sometimes put together in a box with Entity, sometimes it can be separately in a separate box.

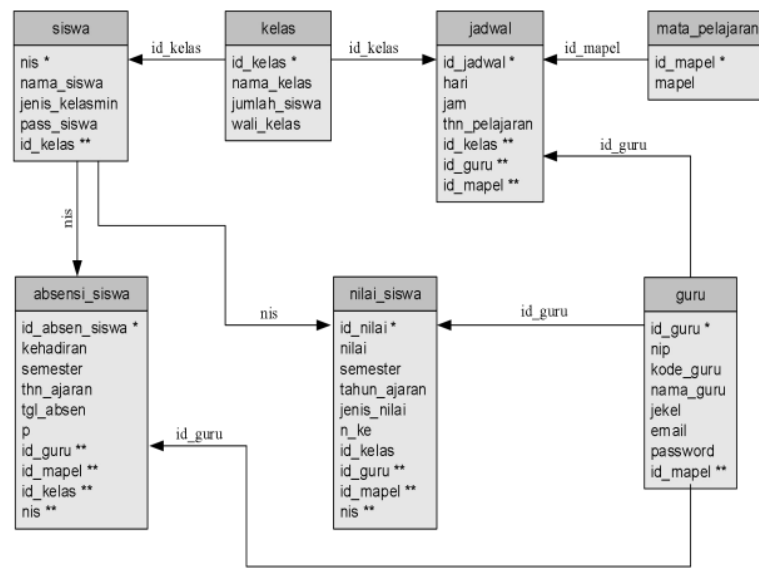

Figure 4. Logical Record Structure Academic Information System MI Nurul Falah

In the Logical Record Structure (LRS) of the MI Nurul Falah Academic Information System is a form of database design used. 
3. Navigation Design

a. Master Page Navigation.

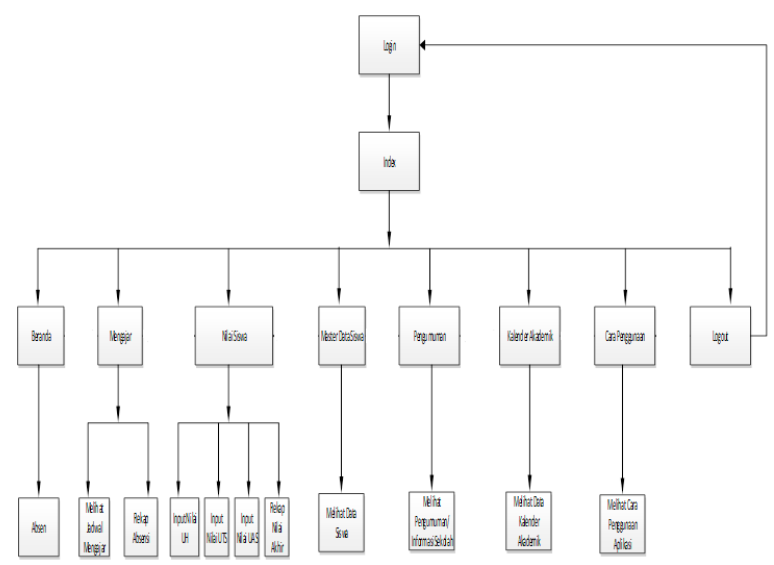

Figure 5. User Navigation Structure of Academic Information System Teacher

The teacher navigation in Figure 5 describes the menu flow that can be selected in the MI Nurul Falah academic information system application.

4. User Interface Design

a. Teacher User Login Page

Figure 6 Explains the user page instructed to enter or input data correctly in order to access the system.

\section{Portal Guru, Silakan Login}

$$
\text { E-mail }
$$

Password

\section{Login}

Figure 6. Initial View of Teacher User Login

b. Teacher Teaching Schedule Data Display

Figure 7 explains the teacher teaching schedule data that has been made by the academic department in such a way that there are no conflicting schedules for days and hours with other classes on the same day.

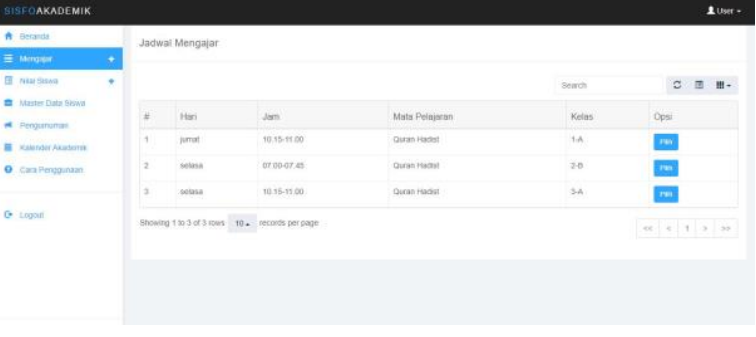

Figure 7. Teaching Schedule Data Display

c. Display of Student's Daily Test Value Data

Figure 8 explains the data on the daily test scores that have been done by students using the online method that is entered into the system.

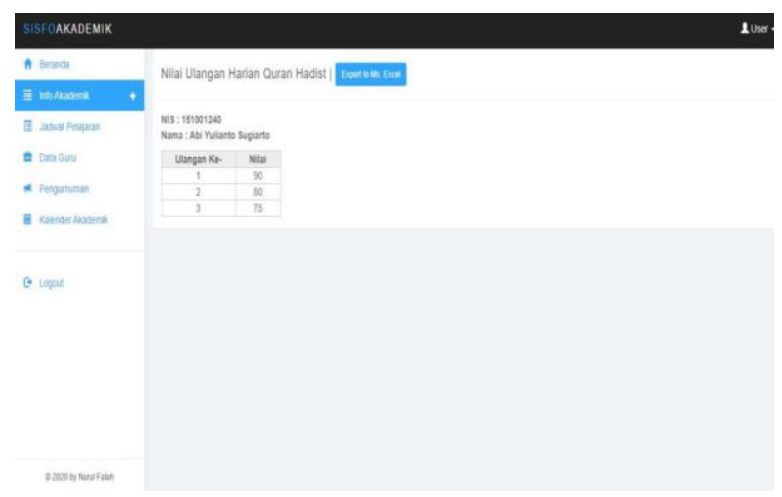

Figure 8. Display of Daily Test Value Data

d. Display of Pure Value Data for MI Nurul Falah students for semester

Figure 9 Displays the data on the results of processing pure class values that are active and has been inputted with attendance data, daily tests, UTS and UAS.

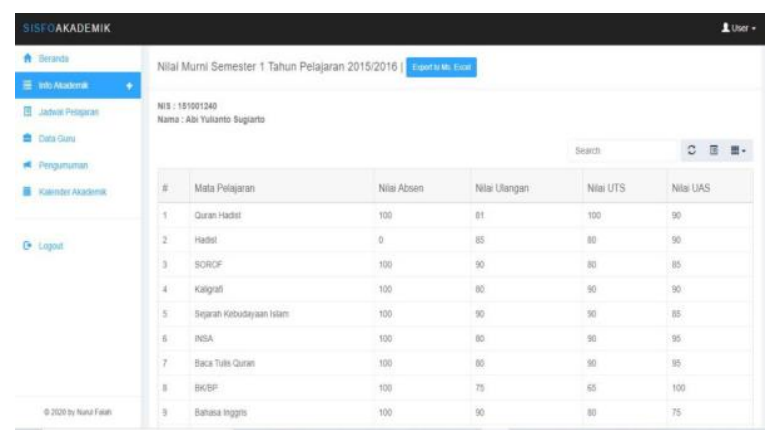

Figure 9. Display value data Pure value processing

e. Display see report card end of semester

Figure 10 shows the final report card page of the semester in one of the classes that has accumulated / calculated the component of the assessment and is displayed in accordance with the KKM (standard grade). 


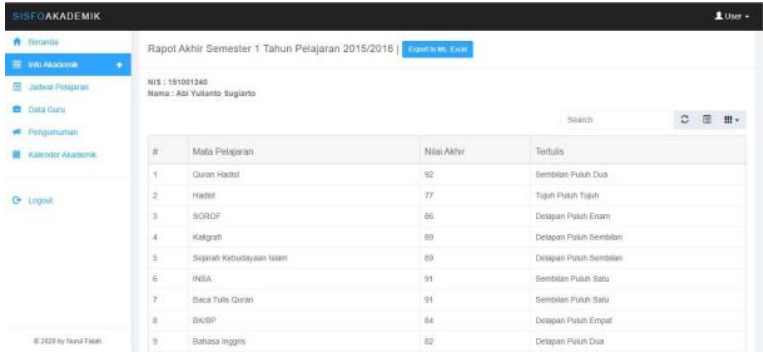

Figure 10. Madrasah Ibtidaiyah Nurul Falah Report Card Semester Display

\section{Software Code \\ 1. Final Score Recap Form}

$<$ ?php

\$idk=\$_GET['id'] ;

\$dtKelas=mysql fetch array (mysql query ("selec t * from kelas where id_kelas='\$idk'")); \$dtMapel=mysql_fetch_array (mysql_query ("selec $t$ * from mata pelajaran where

id_mapel='".\$dtuser ['id_mapel'] ." '") ) ; ?>

$<$ div class="row">

$<$ div class="col-lg-12">

<div class="panel panel-default">

<div class="panel-heading" $>$ Rekap Nilai Akhir

Kelas <?php echo \$dtKelas['nama_kelas']; ?> |

$<$ ?php echo \$dtMapel['mapel']; ?> | <a

href="<?php echo

\$base_url_guru; ?>cetak_rekap_nilai_akhir/<?ph

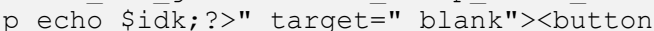

type="button" class="btn btn-primary btnsm" $>$ Export to Ms. Excel $</$ button $\rangle\langle/$ a $\rangle\langle/$ div $\rangle$ $<$ div class="panel-body" $>$

<table border="1" style="border: solid \#CCC

1px; border-collapse:collapse;" $><$ thead $>$

<tr bgcolor="\#EEE">

$<$ td width="20px;"

align="center" $\rangle\langle\mathrm{b}\rangle \#\langle/ \mathrm{b}\rangle\langle/$ t $\mathrm{d}\rangle$

$<$ td width="80px;" $><\mathrm{b}>\mathrm{NIS}</ \mathrm{b}></ \mathrm{td}>$

$<$ td width="280px;" $><\mathrm{b}>$ Nama $</ \mathrm{b}></$ td $>$

$<$ td align="center" $><\mathrm{b}>\mathrm{N}$. Absen $</ \mathrm{b}\rangle\langle/$ td $>$

$<$ td align="center" $><\mathrm{b}>\mathrm{N} . \mathrm{UH}</ \mathrm{b}></ \mathrm{td}>$

$<$ td align="center" $><\mathrm{b}>\mathrm{N} . \quad \mathrm{UTS}</ \mathrm{b}></$ td $>$

$<$ td align="center" $><\mathrm{b}>\mathrm{N}$. UAS $</ \mathrm{b}></$ td $>$

$<$ td align="center" $><\mathrm{b}>\mathrm{N}$. Akhir $</ \mathrm{b}></$ td $>$

$</$ tr $>$

$</$ thead $>$

$<$ tbody $>$

$<$ ?php

\$sqlSiswa=mysql_query ("select * from siswa where id kelas='\$idk' order by nama_siswa asc") ;

while (\$dtSiswa=mysql_fetch_array (\$sqlSiswa)) \{ ?>

$<$ tr $>$

$<$ td align="center" $><$ ?php echo

\$no $=\$$ not $1 ; ;$ ? $></$ td $>$

$<$ td $><$ ?php echo \$dtSiswa['nis']; ? $></$ td $>$

$<$ td $><$ ?php echo \$dtSiswa['nama siswa']; ? $></$ td $>$ $<$ ?php

\$rowAbs=mysql_fetch_array (mysql_query ("SELECT count (*) AS jumAbs from absensi siswa where kehadiran='h' and nis='".\$dtsiswa['nis']." ' and id mapel='".\$dtUser['id mapel']."' and id gurü='".\$ SESSION['idguru'']."' and semester='". \$dtControl ['semester_aktif']."'
And

thn_ajaran='".\$dtControl ['tahun_pelajaran'] ." '") ) ; \$ jumAbs=\$rowAbs [' jumAbs'] ; $\$$ rowUh=mysql f etch_array (mysql_query("SELECT AVG (nilai) A $\bar{S}$ nUh from nilai_siswa where jenis_nilai='uh' and nis='".\$dt Siswa['nis']."' and id_mapel='".\$dtUser['id_mapel'] ."' and id_guru='".\$SESSION['id̄guru']."' and semester='". \$dtControl ['semester aktif']."' and tahun ajaran='".\$dtControl ['tahun pelajaran'] ." ") ) ;

\$nuh=(int) \$rowUh [ 'nUh'] ; $\$$ totA=mysql_fetch_arr ay (mysql query("select * from absensi siswa where nis='".\$dtSiswa['nis']."' and id_mapel='".\$dtUser['id_mapel'] ."' and id guru='".\$ SESSION['ī̄guru']."' and semester='". \$dtControl ['semester_aktif']."' And

thn_ajaran='".\$dtControl ['tahun_pelajaran'] ." ' or̃der by $\mathrm{p}$ desc")) ;

\$na $=($ int) (\$jumAbs/\$totA [ $p$ '] *100);

\$rowUts=mysql_fetch_array (mysql_query ("SELECT

* from nilai siswa where jenis nilai='uts' and nis='".\$ dtsiswa['nis']."' and

id_mapel='".\$dtUser['id_mapel']."' and id guru='".\$ SESSION['id̄guru']."' and semester='". \$dtControl ['semester_aktif']." ' and

tahun ajaran='".\$dtControl ['tahun pelajaran'] ." ") ) ;

\$nuts=(int) \$rowUts ['nilai']; \$rowUas=mysql fet ch array (mysql query ("SELECT * from

nilai siswa where jenis nilai='uas' and nis='".\$dtSiswa ['nis']."' and

id_mapel='".\$dtUser['id_mapel']."' and id guru='".\$SESSION['id̄guru']."' and semester='". \$\$dtControl ['semester aktif']."' and

tahun ajaran='".\$dtControl ['tahun pelajaran'] ."'") $) ;$ nuas $=($ int $) \$ r o w U a s[' n i l a i '] ; \$ a k h i r=(\$ n$ $a * 0.1)+(\$$ nuh*0.2) $+(\$$ nuts*0.3) $+(\$$ nuas $* 0.4) ;$ ?>

$<$ td align="center" $><$ ?php echo \$na; ? $></$ td $>$

$<$ td align="center" $><$ ?php echo $\$$ nuh; ? $></$ td $>$

$<$ td align="center" $><$ ?php echo \$nuts; ? $></$ td $>$

$<$ td align="center" $><$ ?php echo \$nuas; ? $></$ td $>$

$<$ td align="center" $><$ ?php echo

(int) \$akhir; ? $></$ td $>$

$</$ tr $>$

$<$ ?php $\}$ ?>

$</$ tbody $>$

$</$ table $></$ div $></$ div $></$ div $></$ div $>$

\section{Software Testing}

Testing the reliability of the academic information system design at MI Nurul Falah using the Web Application Load, Stress and Performance Testing (WAPT). Testing is done by simulating many users simultaneously with a predetermined time span. In web-based applications, system performance is a critical problem (Andriansyah, 2019). According to (Dhiman, 2018) There are several types of performance tests, namely stress tests, load tests, strength tests and volume tests. WAPT tests the user in stages every 10 seconds, the user will increase by 1 to reach the maximum limit of 20 users for 10 minutes of testing. 


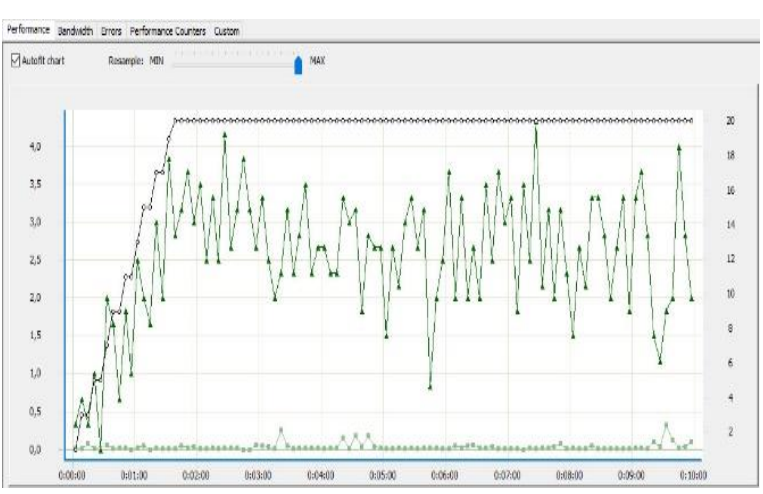

Figure 11. Stress Test Results on the Performance $\mathrm{Tab}$

Figure 11 shows the performance of the website tested by the Stress Test Method and shows pretty good results. In addition to using the following graph, display the results of WAPT software testing in table form.

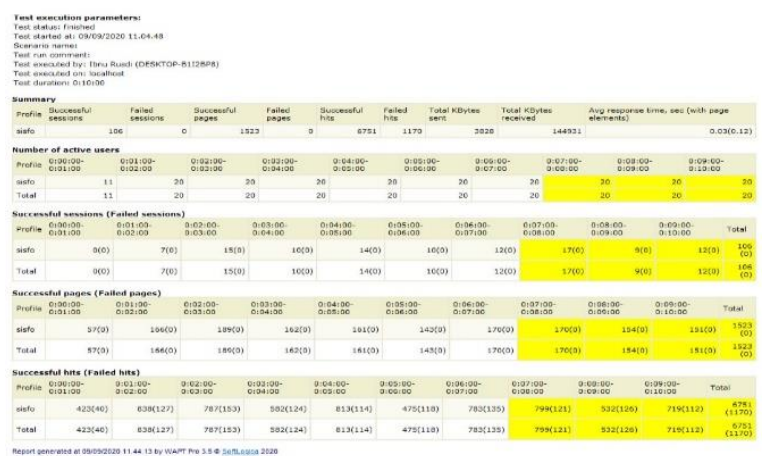

Figure 12. Number of Sessions, Pages and Hits per Minute from the results of the Stress Test

Figure 12 can be explained in the following table form:

Table 2. Number of Total Success and Failed

\begin{tabular}{|c|c|c|c|c|}
\hline No & Name & $\begin{array}{c}\text { Total } \\
\text { Success }\end{array}$ & $\begin{array}{c}\text { Total } \\
\text { Failed }\end{array}$ & Count \\
\hline 1 & Session & 106 & 0 & 106 \\
\hline 2 & Pages & 1523 & 0 & 1523 \\
\hline 3 & Hits & 6751 & 1170 & 7921 \\
\hline
\end{tabular}

Web-based application security is a very important concern, security testing using the Acunetix Web Vulnerability Scanner. The scan results are in the form of security metrics calculations that will display the final score of the Vulnerability Assessments (VA) results (Maharani, Andrian, \& Ismail, 2017).

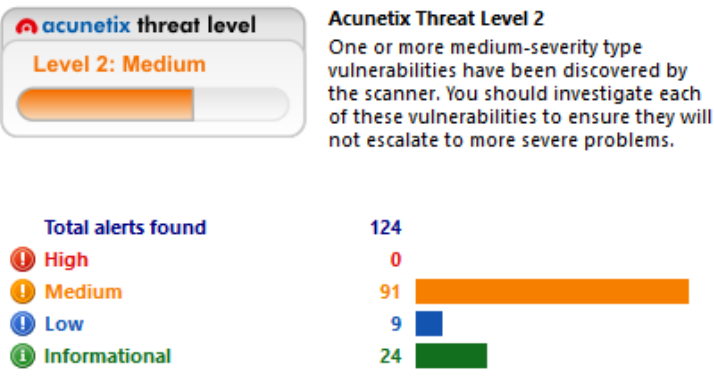

Figure 13. Acunetix Web Vulnerability Scanner Test Results

These results show theat level 2 with the level of security for data at the medium level against vulnerability (Vulnerability) and SQL Injection and Cross Site Scripting (XSS) infections performed by irresponsible people.

\section{CONCLUSIONS AND SUGGESTIONS}

\section{Conclusions}

The process of developing this academic information system was successful in facilitating the development of student achievement, accelerating the process of teacher data collection, plotting teaching schedules and data retrieval to be more effective and efficient because of the webbased system. The process of presenting and delivering academic information to be more effective and efficient is also right on target because data processing has been carried out automatically and kneaded so that all value processing processes to recap grades become faster.

\section{Suggestions}

In making this academic information system there are still many things that need to be addressed so that this application becomes better and more effective. Suggestions for future research are necessary to make access to parents and notification to parents via certain social media to be able to remind important schedules in terms of daily exam implementation, uts and uas as well as regarding payments that have been or have not been completed by parents so that students in the process of working on tests and exams have no obstacles regarding costs and so on.

\section{REFERENCE}

Aediyansyah, A. (2018). Designing a Web-Based Recycling (PET) Sales Information System. INFORMATICS RESEARCH JOURNAL, 1 (1), 11-16. Retrieved from 
http://ejournal.kresnamediapublisher.com/i ndex.php/jri/article/view/5

Anam, K. (2018). Analysis and Design of WebBased Academic Information Systems at $\mathrm{Mi}$ Al-Mursyidiyyah Al-'Asyirotussyafi'Iyyah. Journal of Informatics Engineering, 11 (2), 207-217. https://doi.org/10.15408/jti.v11i2.8867

Andriansyah, D. (2019). Performance and Stress Testing in Optimizing a Website. Computer Based Information Systems Journal, 07 (1), 23-28.

Dhiman, S. (2018). Performance Testing: A Comparative Study and Analysis of Web Service Testing Tools. International Journal of Recent Trends in Engineering and Research, 4 (3), 95-100. https://doi.org/10.23883/ijrter.2018.4102.t buwk

Frieyadie, F. (2019). Belajar Database Logical Record Structure (LRS). Retrieved from http://frieyadie.web.id/logical-recordstructure-lrs/

Friyadie, F., \& Fatayat, U. (2019). Use of Waterfall Model in Designing Web-Based Cosmetics Sales Application. INFORMATICS RESEARCH JOURNAL, 1 (4), 159-166. https://doi.org/https://doi.org/10.34288/jr i.v1i4.84

Hayati, R. (2019). Definition of applied research, types, characteristics, and how to write it. Retrieved from https://pen Researchilmiah.com/pen Research-terapan/

Lesmono, I. D. (2019). Multimedia-Based Animation for Students in the Form of Introduction to the Waterfall Method of Transportation. Swabumi, 7 (1), 20-30. https://doi.org/10.31294/swabumi.v7i1.557 2
Maharani, M. Z., Andrian, H. R., \& Ismail, S. J. I. (2017). Website Security Analysis Using Scanning Methods And Security Metric Calculations. E-Proceeding of Applied Science, 3 (3), 1775-1782.

Novalita, R. (2017). Comparison of Belgian and Indonesian Education. Spatial Journal, 4 (3), 1-10.

https://doi.org/doi.org/10.22202/js.v4i3.23 95.g1349

Rahman, T., \& Pramastya, A. B. (2019). Designing a Website-Based Academic Information System at SMK Bina Medika Jakarta. JSAI (Journal Scientific and Applied Informatics), 2 (3), 208-214. https://doi.org/10.36085/jsai.v2i3.460

Sukamto, R. A., \& Salahudin, M. (2018). Structured And Object Oriented Software Engineering (Revised Edition). Bandung: Informatics. Retrieved from https://scholar.google.co.id/scholar?hl=en\& as_sdt $=0,5 \&$ cluster $=4129280622857038994$

Susanti, M. (2016). Web-Based Academic Information System Design at Pasar Minggu Jakarta Junior High School. Informatics, 3 (1), 91-99.

https://doi.org/doi.org/10.31311/ji.v3i1.30 4

Tan, T. (2020). Ombudsman's Notes on the Implementation of PJJ in the COVID-19 Pandemic. Retrieved from https://www.jpnn.com/news/catatanombudsman-tentang-pelaksana-pjj-di-masapandemi-covid-19

Yuliani, E., Yunita, \& Amalia, H. (2018). Design and Build Academic Information System of Bakti Idhata Middle School. Bianglala Informatics Journal, $\quad 6 \quad$ (1), $\quad 7-13$. https://doi.org/10.31294/bi.v6i1.5898.g328 7 